\title{
Article
}

\section{Social workers understanding of extended family's position in child welfare in Lithuania, Chile and Norway}

by

Siv Oltedal

Professor

Department of Social Studies, University of Stavanger

Norway

E-mail: siv.oltedal@uis.no

Ingunn Studsrød

Professor

Department of social studies, University of Stavanger

Norway

E-mail: ingunn.studsrod@uis.no

Rasa Naujanienè

Assistant Professor

Social work department, Vytautas Magnus University

Lithuania

E-mail: rasa.naujaniene@vdu.lt

Carolina Muñoz Guzmán

Managing Director

Pontifica Universidad Catolica de Chile

Chile

E-mail: cmunozgu@uc.cl

\section{Keywords:}

child protection, cross-contextual research, extended family, family involvement

DOI: https://doi.org/10.31265/jcsw.v15.i1.285

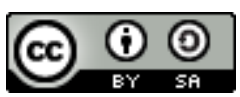

This work is licensed under a Creative Commons Attribution-ShareAlike 4.0 International License. 


\section{Abstract}

Internationally, negotiations between child welfare and protection services and families are a contested area. This comparative study from Chile, Lithuania and Norway uses a vignette and focus groups to explore how child protection workers in various contexts understand families, and how they involve extended families in child protection work. The analysis reveals a fluid and varied understanding of the family and of family practices. The results also show variations across contexts in how they involved extended family members. Norwegian workers tend to lean on a rather riskoriented understanding of families and their impact on children, primarily without involving the extended family. On the other hand, in general Chilean, and to some extent Lithuanian workers, put more of an emphasis on possible resources and in problem-solving within families, relying more on the involvement of-, and support from, the extended families. Hence, extended families` rights and duties regarding the children vary among countries.

\section{Keywords}

child protection, cross-contextual research, extended family, family involvement 


\section{Introduction}

Negotiations between child welfare services and families are an academically, politically and morally contested area (Gilbert, Parton, \& Skivenes, 2011). Even though the family constitutes the central premise for the purposes and arrangement of welfare and protection services (CWS) internationally, family policy and their role vary across nations (Hantrais, 2004), as does child protection practice (Gilbert et al., 2011). In this study, we compare social workers' involvement of extended families in child protection in Chile, Lithuania and Norway. These countries represent different examples of Linda Hantrais' family policy typology (2004). Hantrais (2004) argues that the design and structure of national policy for families differ, as does the level of commitment of state support for family life. She (Hantrais, 2004) claims that defamilialized family policy releases the household of its primary caring responsibilities, due to a coordinated, coherent and explicit public welfare system. By contrast, in a familialized policy context, the state shows weak legal obligations to look after its members, social services are underfunded, uncoordinated and fragmented, and the responsibility of family well-being is left to the families themselves (Hantrais, 2004). Furthermore, in refamilialized welfare regimes, the state has undergone a political shift from a broad and universal provision of support to families, towards a minimalist state and a dominance of an open market (Hantrais, 2004). Family policy typologies may provide a helpful analytical basis when researching comparative social work (Nygren, White, \& Ellingsen, 2018). Hence, in order to comprehend child protection workers' understanding of family and family involvement, we will lean on Hantrais' (2004) typology, which assumes Chile's family policy as familialized, Lithuania's as re-familialized and Norway's as de-familialized.

In order to understand the complexity in family lives, this study also relies on Morgan's (1996) work on family practices. Morgan shows that families can be understood as a set of activities with meanings associated with family at a given point in time (1996: 193-4). Hence, we will understand family in terms of families as a noun, as something fixed and concrete as biological bonds or different family members. While making family an adverb is to describe it in relation to qualities such as sharing common values or being connected by affection. The verb related to families is about how they are implementing and doing, for example, emotional awareness, thus showing how they practise family life. These differences will be 
related to discussions about families and the involvement of extended family in child protection cases.

Comparative child welfare research is evolving (e.g. Nygren, Walsh, Ellingsen, \& Christie, 2020; Gilbert et al., 2011; Walsh, White, Morris, \& Doherty, 2018), as well as research comparing familial understanding and practices across various welfare regimes (e.g. Studsrød, Ellingsen, Guzmán, \& Espinoza, 2018; Oltedal \& Nygren, 2019). Among other things, previous child welfare research has compared key European legislative documents and orientations (Gilbert et al., 2011; Nygren, Naujaniienè, \& Nygren, 2018). Moreover, research of Chilean, Mexican and Norwegian social workers' familial understanding and practices has been compared (Studsrød et al., 2018), in addition to how social workers involve mothers and fathers in various European countries (Nygren, Walsh, Ellingsen, \& Christie, 2018; Nygren, Walsh, Ellingsen, \& Christie, 2020) and comparisons between Chilean, English, Lithuanian and Norwegian social workers' views on children's and parents' position within child protection (Oltedal \& Nygren, 2019). The latter study (Oltedal \& Nygren, 2019) focused on the differences between a society delegating responsibility to the private family and a society setting high ambitions for their welfare services, thus defining families as a public matter.

In this current study, we will explore the similarities and differences in social workers' understanding and questions about: 1) how they understand family as categories and family practices, and 2) how they involve extended families in their practice.

\section{Social policy contexts and involvement of extended family within child protection practices}

The welfare of families and family policy are closely related, thereby influencing the ways in which child protection workers deal with families facing complex problems. In addition to changing family patterns, the relationship between the family and the state probably change worldwide (Thévenon, 2011; Lohmann \& Zagel, 2016). Although it is hard to compare the exact same numbers, statistics measured within a period of 
10 years indicate ${ }^{1}$ that child protection cases have increased in Norway and Chile, while in Lithuania there is a decline in such cases.

Moreover, changings in alternative family formations has not been considered a problem in the Nordic countries, due to social democratic values incorporated within labour market and gender equality policy, hence resulting in more individualized support for family members and a greater pressure on men to become active fathers (Hantrais, 2004). On the other hand, in Lithuania parental breakdown or divorce has created significant numbers of children with no parental maintenance, which has overwhelmed the state system social security funds (CRC, 2020). ${ }^{2}$ The Chilean Civil code does not reflect the changed, and more modern and broader conceptions of family, for instance coparenting (Herrera \& Lathrop, 2016), with Chile being one of the last countries in the world to legalize divorce (Hantrais, 2004).

The tension of involvement in familial matters is predominantly distinct in the area of child welfare and child protection. For example, the Universal Declaration of Human Rights (UDHR) urge states to respect the private life of parents and their freedom of choice of familial life. By January 2020, the European Court of Human Rights had delivered five judgements against the rulings of Norwegian child welfare services, including four violations against the European Convention on Human Rights. ${ }^{3}$ At the same time, the UN Convention on the Rights of the Child (CRC) places the responsibilities on states to intervene in family life, and if necessary, against the will of family members. Due to the highly sensitive and complex nature of this work, an increased emphasis has been placed on legalistic and systemic thinking in most systems (Gilbert et al., 2011).

\footnotetext{
${ }^{1}$ In the selected countries, the number of family issues that appear to be considered public affairs differs. In Norway, the number of families involved in assessments by the child welfare services has increased tremendously, by 190\% over the past 10 years (from 15,761 in 1997 to 45,745 in 2017) (Statistics Norway, 2018). In Chile, a similar trend is evident. In child protection, there has been an increase in cases referred to residential and non-residential services (in 2006 there were 94,675 cases entering into child protection services, and by 2015 this number increased to 116,652) (Gale, 2016). On the other hand, in Lithuania official statistics demonstrate a decline in the number of families who cannot give appropriate care to children (in 2005 there were 16,400 families, and by 2016 this number decreased to 9,700 families) (Statistical Yearbook, 2017).

2 file://fil03/emp01/2900817/Desktop/Litauen.pdf

3 https://www.echr.coe.int/Documents/CP_Norway_ENG.pdf
} 
Differences exists regarding the situation of services, whereas in Lithuania (Nygren, Naujanienè, \& Nygren, 2018) and Chile (Quiroga \& Hamilton-Giachritsis, 2014), welfare systems are partial, underfunded and underdeveloped, in contrast to the relatively affluent situation of services in Norway with a high score on international welfare indexes. For instance, the OECD statistics on social and public expenditures on family reveal that the percentage of GDP spent in 2015 for Chile, Lithuania and Norway was 1.7, 1.6 and 3.4, respectively. Considering the differences in changes of child protection cases presented above, these figures may reveal the refamilialized situation in Lithuania with decreased state resources provided for child protection, while figures show increased state involvement in Chile.

\section{The three countries of the study and the position of the extended family}

The three countries show various traits when it comes to the state-family-child relationship, traits that partly constitute these countries as representative of different policy regimes.

Chile is developing a child welfare system, in which they are striving to adapt to the United Nations Convention on the Rights of the Child (UNCRC) standards. They ratified the UNCRC in 1990, thus indicating a more active role of the state in relationship to families. Nevertheless, it has been argued that 'the best interest of the child' is most often narrowly interpreted as an assurance of child protection, while other rights have been less emphasized (Maclure, 2014). Child protection for children and young people in Chile is primarily managed by private institutions, but supervised and financed in part by the National Service for Minors (SENAME) (Quiroga \& Hamilton-Giachritsis, 2014). Still, organizations have mostly limited resources, and are dependent on charity to collect funds, which heavily impairs the quality of care for the children (Muñoz-Guzmán, Fisher, Chila, \& LaBrenz, 2015). Family change and socio-economic modernization go hand-in-hand with the growing importance of the support provided from the extended family (usually three-generational) households, and poor and employed women (usually responsible for child care) in particular need all the help they can get from their relatives (Palma \& Scott, 2020). The legislation is a poor instrument in dealing with social and economic changes after the family breakdown (Herrera \& Lathorp, 2016). At the same time, the state is more willing to intervene in families; Jeldres and Marchant (2018) have stated that it is necessary to 
focus on the violence with which the system treats poor families, most of them headed by a single woman. The Chilean policy defends the rights of the birth parents and the birth family, emphasizing the importance for both children and their parents to maintain the family as a goal of social policy and intervention (Fox, 1997: 70). In general, extended families, such as grandparents, are a very important part of the helping and support system for child welfare workers working with child protection. Moreover, although limited, the foster family services are mainly implemented through kindship families (Muñoz-Guzmán et al., 2015).

In Lithuania, the adaptation to UNCRC standards is ongoing. Officially acknowledging the UNCRC in 1995, the Law of the Republic of Lithuania on Fundamentals of Child Rights Protection was adopted in 1996. Various types of child maltreatment, including violence, were first banded according to laws in 2017 (Tamutiene, 2018). The office of Ombudsman for Children Rights was established in 2000. Since 1 July 2018, child protection has been centralized from the municipality to the national level, and the State Child Rights Protection and Adoption Service was reestablished. It is the central institution for the protection and defense of the rights of the child that implements the Children Rights Protection Policy in the territories of the municipalities, and participates in the process of the state policymaking in the field of Children Rights Protection itself or through its territorial structural divisions. ${ }^{4}$ In the 'Law on the Fundamental Rights of the Child' (1996), extended family is named implicitly in several cases. The child has the right to live with his/her parents, and it must be guaranteed the right to communicate with close relatives, as well as with other relatives of the child with whom the child has emotional ties. The extended family is explicitly defined as parents or their other representatives under the law, brothers and sisters of the child, grandparents and other people living with the family (Description of case management, 2019). The legislation indicates that the close relatives of a child who wish to become guardians of the child are not required to attend training for caregivers (Child custody, 2019).

As one of the more affluent northern European countries, Norway, which ratified the UNCRC in 1991 and incorporated the convention in the laws in 2003, is

\footnotetext{
${ }^{4}$ http://www.vaikoteises.It/vaiko-teisiu-apsauga/sistema-lietuvoje/
} 
characterized by de-familiarized family policies. Norway provides a wide range of public welfare such as education-, health- and social services to children and families. There is an aim to diminish the reliance of individuals on their families. The CWS is an integral part of the larger welfare state, and has traditionally had a familysensitive and therapeutic approach to family and children (Skivenes, 2011). There is a class issue when statistics reveal an overrepresentation of poor families in Norwegian child protection (Kojan \& Fauske, 2011). The extended family, such as aunts, uncles and grandparents, usually have no legal obligations to take care of their child relative, and in contrast to Lithuania, they are not mentioned in the law. The extended family is most often without rights in CWS proceedings, even though in practice many play a vital role in many regards. According to the law (Children Act [Barnelova], 1981), parents are entitled to, obliged to take care of, to decide on behalf of, or otherwise to care for children. Nevertheless, recent child welfare policy urges services to encourage the family and network to take part in problem-solving (NOU, 2016:16).

If children are placed in out- of- home care, the preference is foster care. The child welfare act (CWA § 4-22) introduced a new demand in 2018, saying that services must investigate whether the child can be placed in kinship care, and preferably choose kinship care if possible. Even so, there has been a tradition for a general scepticism among social workers towards kinship care, especially toward grandparents who did not succeed in raising the child's parent (Havik \& BackeHansen, 1988).

\section{Material and Methods}

This article draws on material from the larger international comparative project, 'Family Complexity in Social work' (FACSK). The project was founded by NORFACE, with the data collected during 2016 from child welfare services. All participants were provided by the same specific case vignette with a complex family situation (see Figure 1). An intensity sampling method (Morris, 2006) was used, in that participants who could offer rich information about their CWS work in large municipalities were invited to participate. 
The vignette was constructed as an evolving story about a complex family situation that the focus groups were asked to respond to, consisting of the stages addressing different angles for discussion, e.g., mental health problems, alcohol abuse, migration and child welfare, and include extended family and organizational resources. It was developed by an international team of researchers at the outset of the study. The vignette is summarized below for the readers' orientation (adapted from Walsh et al., 2018, p. 4) $)^{5}$

\begin{abstract}
Maria and David live with their three children, Beth (5), John (8) and Thomas (20), who has a different father with whom he has lost contact. Maria is unemployed, and David works unpredictable hours. David migrated to Chile/Lithuania/Norway/UK, and has no relatives living there. Maria and David's relationship is volatile. Maria has a history of heavy drinking and drug use. Sometimes, Maria and the children have gone to stay with Maria's brother (Paul) and his wife (Hannah) ... Maria and Paul's parents live outside of the city; they have expressed negative views about Maria and David's relationship, and there is also little contact with them.

The three stages in the focus group address different angles for discussion: mental health problems, alcohol abuse, migration and child welfare, and include extended family and organizational resources.
\end{abstract}

Figure 1: Summary of the vignette

We provided common questions related to the vignette such as: How do you see this situation? What would you as a social worker do in this situation? How/why? The focus groups were audio recorded, transcribed verbatim and translated to English from the locally used languages.

Data is derived from five focus groups $(n=27)$ in three different contexts: Norway (two groups with seven and eight participants), one Lithuanian group (eight participants) and two Chilean groups (with two and two participants, respectively). We applied a

\footnotetext{
${ }^{5}$ The full vignette, and the instructions given to the focus groups, are available at https://www.umu.se/globalassets/organisation/fakulteter/samfak/institutionen-for-socialtarbete/dokument/facsk/facsk-vignette-english.pdf
} 
thematic analysis as a method for identifying themes within the data (Braun \& Clarke, 2006), which offers an accessible and theoretically flexible approach to analysing qualitative data (Braun \& Clarke, 2006); thus, it is well suited for our purposes. We familiarized ourselves with the data, and in order to conduct the analysis, we carved out and selected pieces of the data, identified codes and applied these to the data.

It is important to note the limitations of this study; we must be cautious in how we draw conclusions, and also from country-specific patterns, due to, for example, few participants (especially in Chile) and various organizations for welfare services. We need to take into account that such case descriptions will construct the discussion in specific ways, and leave uncovered other parts of actual practices. Our participants' experiences may differ from that of others. This may create challenges when we are comparing social workers' understandings of families and social work practice. Although the vignette is the same in all contexts, we do not present dominant discourses in the different countries, which could help validate differences in the interpretation of the vignette. Working with translated data in qualitative research has its limitations (Nikander, 2008). However, the data were validated due to collaboration between native researchers involved in the data collection phases.

There are demonstrated potentialities in using a case to stimulate 'thinking as usual' among professionals, such as the one used in this project (Nygren, White, \& Ellingsen, 2018). The vignette approach with thoroughly pre-designed questions also increases coherency across countries, and allows for variations (Nygren \& Oltedal, 2015). Hence, the vignette describes a complex family situation that enables social workers from different countries and working in different service areas, e.g., child welfare, to disclose their conceptions of family interventions.

\section{Results}

When analysing the similarities and differences between child protection workers in Chile (FG-C), Lithuania (FG-L) and Norway (FG-N), we relate this to the following themes: 1) the fluid and varied understanding of family, and 2) the comprehensive and restricted involvement of the extended family. In the following, we present how focus group accounts from child protection workers are represented in relation to these themes. 


\section{Theme 1: The fluid and varied concept of family}

First, a common characteristic is to understand family as a noun. Although biology is one of the main characteristics when defining a family everywhere, the focus group discussions also show several additional understandings. Participants talk about the family' and give 'it' a fixed, reified quality, such as members sharing biological bonds, legal ties, finances and/or households. Family as biology may influence various types of support, such as economic support in this Lithuanian example:

(Financial) compensation for heating is given only if the children have parenthood, because sometimes the fathers are not the ones that they are living with, so it is not determined as to whether they will get the compensation. (FG-L)

The family does not necessarily live in the same household. Participants state variations as families that consist of two-person households, cohabitation and transnational families, as well as the more traditional nuclear- and multi-generational families. For instance, the Lithuanian participants deliberate on a familial case, in which the mother is the breadwinner and works in Germany some months of the year, while the grandmother stays in Lithuania and is the caretaker of the children. Furthermore, participants reveal that 'family' may be hard to grasp, and is not easily understood:

In fact, this new type of family isn't being visualized, which is a lot more complex, a lot more dynamic, by itself, a lot more changeable. (FG-C)

The class perspective is also a way a participant characterizes families. Children are born into families with a history, being, for example, fixed in a position as wealthy or poor. In all contexts, low-income families are the issue. The Chilean and Lithuanian participants primarily talk about low-income families in contact with their services, whereas the Norwegian group also discusses wealthy families.

A second common usage is to give family relations diverse and particular qualities or characters, thereby making family an adverb. When asked openly, participants mention positive characters, such as families, being a 'bond of love that unites people' (FG-C) and 'supporters and partners' (FG-N). Focus group participants argue that what counts as family members are some type of connection, a possible source of affection and various types of support. Nonetheless, statements concerning the vignette usually reveal negative accounts of the families. Participants describe a range of characteristics of family risks and structural, cultural and functional 
problems, using everyday language, legal terms and professional jargon such as 'a great deal of trouble' or 'in crisis'. Adverbs are also used, including 'divorced', 'recomposed' and 'dysfunctional' families.

Across all contexts, familial problems are issued at various levels. Participants tend to view the family themselves as the cause of familial problems, and/or as a context in which problems are developed and maintained, as in these examples from Chile and Norway:

I don't know if I should talk about family of origin, but it's typically known, and through these processes the problems are also maintained. (FG-C)

It's often the case that childhood lasts generations. (...) which can mean that family can cause a great deal of trouble, which makes it difficult to produce change in a family. Because it is so, yes, I don't like to say deadlocked, but l'Il say it. Yes. (FG-N)

It is a contested issue to talk about social heritage, that problems go through generations, in Norway and Chile, while in Lithuania this issue is referred to as a system theoretical type of reasoning. This vignette stimulates more talk about familial problems than resources. Still, families are also described in a more neutral way, using metaphors such as 'networks', 'changeable' and 'dynamic'.

A third common usage is to make family a verb, when talking about how individuals do family, with the participants worrying about families that have little to offer children (e.g. in money, protection, provision or stimulation). The Norwegian participants also worry about families that overdo their parenting. The Norwegians meet wealthy parents, putting high expectations and a lot of stress on their children, thus placing their children at risk:

Yes, so parents are far more involved in the children's everyday lives for better and for worse, perhaps often over-involved.

Yes.

They can't breathe. Children can't even go to football training alone because they're going to follow them, sort of.

Yes, it's just like that. (FG-N)

The Lithuanian participants give another example of family display, emphasizing a lack of familial resources and efforts, which creates various types of risk due to a family display on the margins: 
But I know from my experience that five babies with the age difference of a year were taken from this family three times. So the mother said she would prepare a three liter jar of instant tea, pour it into bottles and give it to her children. No food. So you imagine what they were. I called the ambulance and took them, but I still was attempting to get them to kindergartens so that they would have something to eat, and I would arrange with the director that the children would have some food given for Saturdays and Sundays. But the mother and her friends would eat it. She would again make that water for the children. (FG-L)

All participants demonstrated their efforts to understand and assess various family doings, positions, interactions, strengths and problems, and to act accordingly:

And we do think a lot about family, for better or worse. So it's always the family that is the main focus here, and if there is someone, is there anything to gain, or sort of, is there nothing to gain? Do they have a positive effect or negative effect on the people concerned? (FG-N)

Although participants differ in how much risk or solutions they may find in families, they held a common view that their works consisted of having child protection in mind:

First, look at the children's situation, how are they, is it necessary to file a report, put a protection measure, look for a family if the children have to get out of the house because the situation of abuse is that serious, if the mother is consuming drugs, how negligent can the caretaking of the children be; I mean, first look at how the situation is. $(\mathrm{FG}-\mathrm{C})$

All in all, participants highlight the complex, conventional and unconventional nature of families referred to their services, and they share a varied and fluid family understanding. How child welfare workers define family is linked to the complexities of characteristics and to normative assessing, and to grasp and observe family practices in the doings of everyday life.

\section{Theme 2: The comprehensive and restricted involvement of the extended family} In all contexts, it is the situation of the child that causes the child protection worker to become preoccupied with the composition and display of the family. When talking about how to solve the situation in the family, participants exhibit different views about what family members to include, and when to include them. Participants' reliance on-, and inclusion of the extended family and network varies across contexts.

First and foremost, the Norwegian participants tend to control the nuclear family, and to hold them accountable. They argue that the extended network is not a part of the 
assessment process in legal terms; hence, they are merely occupied with the child and the nuclear family. These participants will involve extended family first if out-ofhome placements and foster-care are needed, saying:

We could base our work on both short-term and long-term goals. It's a bit like, first you ensure that the children are okay, then... it would be very exciting to gather the whole bunch [mother, father and children] here. (FG-N)

Participants from Norway seem more inclined to issue possible risks in the family environment. Their concern is firstly about domestic violence, but they also talk about issues such as drug abuse, mental health problems and a lack of attachment. They are preoccupied with assessment. As social workers, they mean that parents must be able to understand the children and see the tempo they are developing at, and to provide safe and supportive care. Nevertheless, they think it is up to them as child welfare/protection workers to control, assess and evaluate whether the care in the family is 'good enough', and to secure that children are safe within the family. Their assessments and evaluations therefore become more prevalent than problem-solving within the family.

The role of finances, laws and regulations also differs across contexts. The Norwegian groups talk about comprehensive services, in which resources are allocated to focus on family support, in addition to child security and well-being across different health and welfare services. They argue that laws and regulations push forward new and more social work practices with families. For instance, they show that lately they have increased their inclusion of- and reliance on family and networks, even in foreign countries, and that: 'There are a few, some circulars and regulations [for child protection work] that say that you actually must check out the family in other countries as well' (FG-N).

In the Norwegian group talk, the connection between policy and practice is considered to be strong, because the workers often refer to paragraphs in the laws that regulate the child protection system. Participants mediate that the child protection system is coherent, and that they themselves have confidence in the system and in bureaucratic hierarchies. The range of their discretionary action is reflected in how they discuss specific situations, and interpret the law as a help to balance what is worst or best for the child. In case of possible out-of-home 
placements, they would strive to formalize these placements by referring to specific paragraphs in the legislation. They tend not to accept a lower foster home standard if that would be a consequence of placing children within the extended family.

The Lithuanian participants also prefer to involve the nuclear family first, and later to broaden their family involvement; as one in the Lithuanian group put it: 'I would not work with the [closest] relatives at this point', which is supported by another group participant: 'If you address the relatives too early, so then they [the biological parents] transfer their problem to them [the extended family] and stop looking for a job or do anything.'. Extended family members may feel obligated to take over and solve the situation. Nonetheless, the Lithuanian participants are not entirely positive about involving the extended family, since they believe extended family members are also unreliable, irresponsible and unwilling to help the child and the nuclear family, and that they need help from workers to understand their roles. As a result, these participants say that the relationships and obligations between nuclear and extended members may compensate as well as deprive family services, and even create more work for social workers.

The analysis also reveals different practice models with various emphases on familial strengths and risks. The Lithuanian participants highlight the controlling function of their services; as they look to how parents are demonstrating responsibility, they also look for familial strengths:

I see the strengths coming; that woman Maria is asking for help herself. (...) It would be good to focus on those strengths and at least start with something so that the woman would find inner strengths in herself. (FG-L)

These participants are also focusing on problem-solving: 'that the adult problem just has to be solved' (FG-L). Even though they express several problem areas, such as cultural problems, familial survival, no income, drug and alcohol consumption, disagreements about the upbringing of children, broken familial relationships, a lack of support from the family and mental health problems, as from early on they primarily look for possible solutions to familial and social problems.

Although the Lithuanian participants do not explicitly talk about family politics, their talk reveals that politics clearly effects service delivery. They seem to work under a 
system in which they are expected to exercise control in relation to social allowances, and to encourage parents to find employment. This includes working with parental motivation and responsibility, in addition to controlling measures and putting pressure on parents. Parents need to be educated and encouraged to not exploit public resources; as one participant expressed, 'We must save the state's money' (FG-L). As shown above, parents must even be educated and controlled in order not to abuse resources. Participants refer to when Lithuania was under the Soviet system and the state had a strong role, while now the policy demands more of the families in the area of child welfare. They also talk about the need for-, and lack of interprofessional cooperation and communication across services. Services are sometimes far away or unavailable, as family therapy depends on available resources. Benefits to families are low, which also reduces the options to achieve changes and highlights the lack of trustworthy services.

The Chilean participants are rather positive toward the extended family altogether, and will include the extended family from early on. They also prefer to leave it up to the family themselves to solve the problem, and motivate the family to help each other, if possible.

These participants are eager to involve the extended family. However, if there are troubles or conflicts in extended families, they will try to obtain access to external resources. They also show that their actions depend on court decisions:

The court decides, and we have access to the whole family of the child, because here it says two siblings, but what happens a lot is that the family hides the extended family from us. Or they say (...) that there's no one who wants to take care of the child. (FG-C)

The Chilean participants report that regulations, politics and measures pull back their practices with families, because the tools used in practices ' $(. .$.$) aren't modified in the$ function of $(. .$.$) this new vision or conception of family' (FG-C).$

Participants say that they aim to use all available resources, and that they would contact 'the whole world', e.g., the school system, to protect the children. Yet, they refer to the lack of trustworthy services, and resources, the situations of ideals and realities, and to the strong emphasis on the family's responsibilities: 'The residence system is terrible in Chile', which make them prioritize family measures. They show 
that arguments for separating children from their families is related to a categorization of 'child protection families', and not to the needs of the individual child. Focus group participants also feel they lack discretional power. They try to make themselves responsible for decisions, but are aware of the limitations that follow from a hierarchical social policy tradition, in which an authoritarian state is exemplified by a court decision about what is in the best interest of the child.

\section{Discussion}

In this current study, we explore the similarities and differences in social workers' understanding, and questions: 1) how they understand family as categories and family practices, and 2) how they involve extended families in their practice. The analysis reveals significant and thematic differences and similarities among the three countries.

Participants give 'the family' a fixed, reified quality. At the same time, they reveal a varied and fluid understanding, focusing on various phenomena, such as socialeconomical structures and familial roles, and different types of bonds and ties, as well as describing risk and resourceful activities, showing the complexity of family, and similar to the work of the family practices of Morgan (2003). Morgan's (2003) concept of family practices incorporates a fluidity, diversity and multi-facetedness in analysing contemporary families. Participants' discussions show that across socio-economic, structural and other contingencies and constraints, social workers deliberate on parents' efforts in being and doing family. They thereby focus on- and exercise judgements of who to involve in their work, and on various 'family displays' (Finch, 2007). Doing family, e.g., with a poor or wealthy family differs regarding how parents are involved in, or able to support children's everyday life, and will influence social workers' assessments and measures. These judgements also demonstrate how social workers believe that various types of family display constitute risks and resources.

The findings reveal that in practice the involvement of extended families seems to differ regarding social-economic factors. A lack of resources seems to have a strong influence on decisions, and on whether to involve the extended family, in both Chile and Lithuania. The finding is in line with results elsewhere, showing the fragmentation 
and lack of services in Lithuania (Kabasinskait \& Bak, 2006) and in Chile (Quiroga \& Hamilton-Giachritsis, 2014). Consequently, social workers in these countries must view the resource situation within the extended family when deciding on child welfare issues, and if possible, place responsibility over them. Moreover, the Lithuanian and Chilean participants merely talk about poor families in contact with their services, reflecting the modest measures and support within social services only reserved for the families and children most in need (Nygren, White, \& Ellingsen, 2018). By contrast, the Norwegian child protection workers also meet and assess wealthy families. This might reflect their family service orientation, in which interventions do not merely respond to maltreatment or the gross neglect of children, but entail provisions or services aimed at enhancing children's well-being, and to family support (Skivenes, 2011). This is probably also due to the affluent, socio-democratic welfare state having strong redistributive and egalitarian values (Forsberg \& Kröger, 2010), and relatively more resources to spend on family services (OECD, 2020). Although the resource issue is not used as an independent argument among Norwegian participants, we have reasons to believe that they also need to respect the budget; however, they seldom use this as an independent argument for how and whether they involve families.

Social workers' involvement of extended families occurs within different national and social political contexts. These findings are somewhat in line with Hantrais' model (2004). Chilean participants seem inclined to rely on extended family members and to lean on a non-interventionist approach, in accordance with familialized regime (Hantrais, 2004). The Norwegian participants seem to mostly rely on the extended family, but transfer responsibility to the state, which is line with a defamilialized welfare regime (Hantrais, 2004). On the other hand, the Lithuanian participants seem more diverse, although they talk more about the past, thus illustrating the transference of services, in line with the theorizations of a refamilialized state (Hantrais, 2004). Nevertheless, they are reluctant to trust extended families, but also inclined to use a non-interventionist approach.

There are differences regarding laws and resources, with those contextual factors influencing social workers' professional discretion in child protection cases (Gilbert et al., 2011), as also shown in the findings. The findings also reveal that the Norwegian 
workers seem more problem-oriented than their partners, which could reflect the Norwegian law (CWA, 1992), encouraging staff to investigate sufficiently before issuing supportive or controlling measures.

In Chile, the lack of public resources, in combination with family-oriented values, enhances the involvement of the extended family, as also shown in previous research (Palma \& Scott, 2020). In Lithuania, there is also a lack of public resources and a restriction towards using public resources, as well as a partial involvement of the extended family depending on avoiding the misuse of resources. In Norway, the groups demonstrated preferences for using public interventions and the space for action given by legislation, as well as a restrictive attitude towards the involvement of the extended family.

The analysis of social workers' understanding in the three countries reflect different orientations on how, as child protection workers, they are part of a system in which responsibilities for the children are either comprehensive or more restricted, as illustrated in Figure 2.

\begin{tabular}{|l|l|l|l|}
\hline & \multicolumn{3}{|l|}{ The size of the child welfare provision } \\
\hline $\begin{array}{l}\text { Involvement of } \\
\text { extended family }\end{array}$ & Comprehensive & Partly & Restricted \\
\hline Comprehensive & & Familialized (Chile) & \\
\hline Partly & & & Refamilialized (Lithuania) \\
\hline Restricted & Defamilialized (Norway) & & \\
\hline
\end{tabular}

Figure 2: Complexities of welfare size and type of family involvement Norway has comprehensive welfare services. There is a restrictive attitude regarding the involvement of the extended family during the entire process, unless they are in need of out-of-home care, although politics has put an increased emphasis on the family and network to take part in problem-solving (NOU, 2016:16).

The welfare services in Chile are struggling with lack of resources, which is needed to achieve a higher standard. The extended families have a tradition of being of importance in child welfare, and which are still important.

In Lithuania, there is a rather severe lack of resources, and from the Soviet time there is also an opinion to not use too much of the state's money. There is a partial 
involvement of the family, because there is also a critical voice towards the families, thereby avoiding them from 'making money' from child welfare issues.

\section{Conclusion}

To comprehend the complexities of family definitions, this study has shown the value of relating this to a noun as a concrete description, as an adverb related to qualities and as practicing in doing family life. Related to the law, there is a difference between countries as to how extended relatives are given rights and duties. In all countries, most of the families involved in child protection issues are poor and troubled. They are being evaluated regarding family doings such as drug abuse and violence (which was illustrated in the vignette), in addition to other troubled family practices, such as (problematic) social heritage, and failing emotional, social, economic- and practical child-care.

This comparative study from Chile, Lithuania and Norway has explored how child protection workers understand families, and how they involve extended families in child protection work, thus indicating contextual differences and similarities. A similarity in Chile and Lithuania is that the extended family has a rather strong position, whereas among the Norwegian participants their position seems significantly weaker, similar to Hantrais' model (2004). In the Norwegian example, workers hesitate to privilege extended families because there is a rather narrow orientation on children and their interests. Family belonging is seldom not an independent argument on its own in the Norwegian talk. However, resources and a lack of available foster homes in Norway, Chile and Lithuania may help strengthen the extended family position, as they may feel a moral duty related to providing care.

\section{Funding}

This study was funded by the NORFACE/Welfare State Futures Programme. 


\section{References}

Braun, V., \& Clarke, V. (2006). Using thematic analysis in psychology. Qualitative Research in Psychology, 3(2), 77-101. https://doi.org/10.1191/1478088706qp063oa

Child custody (2019). Order on "Provision of child custody" of the Government of the Republic of Lithuania. Updated November 20, 2019, No. 1173. Child protection in Lithuania. http://www.vaikoteises.It/vaiko-teisiu-apsauga/sistema-lietuvoje/ [Accessed 20.12.2019].

Children Act (1981). [Barnelova], Norway. [Barnelova -LOV-1981-04-08-7: Lov om barn og foreldre (1981)] https://lovdata.no/dokument/NL/lov/1981-04-08-7 CRS (2020). file://fil03/emp01/2900817/Desktop/Litauen.pdf

CWA, Child Welfare Act (1992). Norway [Barnevernloven: LOV 1992-07-17-100: Lov om barneverntjenester (1992)] https://lovdata.no/dokument/NL/lov/1992-07-17100

Description of case management (2019). Order on "Approval of a case management procedure description" of Minister of Social Security and Labour of the Republic of Lithuania, December 30, 2019, No. A1-802.

Finch, J. (2007). Displaying families. Sociology, 41(1), 65-84. https://doi.org/10.1177/0038038507072284

Forsberg, H., \& Kröger, T. (2010). Social work within 'a welfare paradise'. In H. Forsberg \& T. Kröger (Eds.), Social work and child welfare politics Through Nordic lenses (pp. 1-9). Bristol: The Policy Press.

Fox, H. L. (1997). Perspectives in Child Care Policy. London, UK: Longman Group.

Gale, C. (2016). Alternative Child Care and Deinstitutionalisation. A case study of Chile. CELCIS Centre for Excellence for looked after children in Scotland. Retrieved from https://www.sos-childrensvillages.org/getmedia/dbd9ada6-334b45bf-8c9f-b2a1757cc4dc/Chile-Alternative-Child-Care-andDeinstitutionalisation-Report.pdf

Gilbert, N., Parton, N., \& Skivenes, M. (2011). Child Protection systems: International trends and comparisons, New York: Oxford University Press. https://doi.org/10.1093/acprof:oso/9780199793358.001.0001

Havik. T., \& Backe-Hansen, E. (1988). Kunnskapsstatus for fosterhjemsarbeidet [A status knowledge for foster care practice], Bergen: Nova. 
Hantrais, L. (2004). Family policy matters: Responding to family change in Europe. Bristol: The Policy Press. https://doi.org/10.2307/j.ctt1t893wm

Herrera, M., \& Lathop, F. (2016). Parental responsibility: A comparative study of Latin American legislation, International Journal of Law, Policy and the Family, 30, 274-291. https://doi.org/10.1093/lawfam/ebw010

Jeldres, M., \& Marchant, M. (2018). Ley de Adopción: Un proyecto que facilita quitarle los hijos a las familias marginadas [Law about adoption]. https://ciperchile.cl/2018/06/28/ley-de-adopcion-un-proyecto-que-facilitaquitarle-los-hijos-a-las-familias-marginadas/

Kabasinskaite, D., \& Bak, M. (2006). Lithuania's children's policy in the period of transition. International Journal of Social Welfare. 15, 247-256. https://doi.org/10.1111/j.1468-2397.2006.00428.x

Kojan, B. H., \& Fauske, H. (2011). Et klasseperspektiv på barnevernets familier. Tidsskrift for velferdsforskning, 14(2), 95-109.

Law on the Fundamental Rights of the Child of the Republic of Lithuania (1996). Vilnius, March 14, (updated version since August 31, 2019).

Lohmann, H., \& Zagel, H. (2016). Family policy in comparative perspective: The concepts and measurement of familization and defamilization. Journal of European Social Policy, 26(1), 48-65. https://doi.org/10.1177/0958928715621712

Maclure, R. (2014). Introduction to children's rights in Latin America: Constraints and possibilities. International Journal of Children's Rights 2(22), 235-239. https://doi.org/10.1163/15718182-02202007

Morgan, D. H. J. (2003). Introduction, In D. Cheal (Ed.), Family critical concepts in sociology (1-17). USA, Canada: Routledge.

Morgan, D. (1996). Family connections. Cambridge: Polity press.

Morris, T. (2006). Social work research methods: Four alternative paradigms Thousand Oaks, California: SAGE Publications.

Muñoz-Guzmán, C., Fisher, C., Chila, E., \& LaBrenz, C. (2015). Child welfare in Chile: Learning from international experiences to improve family interventions, Social Sciences 4, 219-238, https://doi.org/10.3390/socsci4010219

Nikander, P. (2008). Working with Transcripts and Translated Data Qualitative Research in Psychology, 5:3,225-231. https://doi.org/10.1080/14780880802314346 
NOU (2016: 16). New children act [Ny barnevernslov — Sikring av barnets rett til omsorg og beskyttelse] downloaded 9th of January 2020.

https://www.regjeringen.no/no/dokumenter/nou-2016-

16/id2512881/?q=Barnevernsloven\&ch=21

Nygren, K. Naujanienè, R., \& Nygren, L. (2018). The notion of family in Lithuanian and Swedish Social Legislation. Social policy \& society. 17(49), 651-663. https://doi.org/10.1017/S1474746418000192

Nygren, L., \& Oltedal, S. (2015). Constructing a vignette for qualitative comparative family research. Journal of Comparative Social Work, 10(1), 73 - 76. https://doi.org/10.31265/jcsw.v10i1.123

Nygren, L. White, S., \& Ellingsen, T. E. (2018). Investigating welfare regime typologies: Paradoxes, pitfalls and potentialities in comparative social work research. Social Policy \& Society 17(4), 665-677, https://doi.org/10.1017/S1474746418000167

Nygren, L. White, S., Ellingsen, T. E., \& Christie, A. (2020). Gender, Parenting and practices in child welfare social work? A comparative study from England, Ireland, Norway and Sweden. The British Journal of Social Work 0, 1-18. https://doi.org/10.1093/bjsw/bcaa085

OECD (2018) Chile Febrero 2018: vision general. Estudios económocos de la OECD. Retrieved from https://www.oecd.org/eco/surveys/Chile-2018-OECDeconomic-sruvey-Spanish.pdf

OECD (2020). How is life? 2020: Measuring well-being, Index Data, OECD Publishing, Paris https://stats.oecd.org/Index.aspx?DataSetCode=BLI

Oltedal, S., \& Nygren, L. (2019). Private and public families: Social workers' views on children's and parents' position in Chile, England, Lithuania and Norway. Journal of Comparative Social Work, 14(1), 115 - 140. https://doi.org/10.31265/jcsw.v14i1.235

Palma, J., \& Scott, J. (2020). The implications of changing living arrangements for intergenerational relations in Chile. Contemporary Social Science. 15(3), 392405. https://doi.org/10.1080/21582041.2018.1460487

Quiroga, M. G., \& Hamilton-Giachritsis, C. (2014). 'In the name of the children': Public policies for children in out-of-home care in Chile. Historical review, present situation and future challenges. Children and Youth Services Review. 44, 422-430https://doi.org/10.1016/j.childyouth.2014.07.009. 
Skivenes, M. (2011). Norway: Toward a child-centric perspective. In N. Gilbert, N.

Parton \& M. Skivenes (Eds.), Child Protection systems: International trends and comparisons, New York: Oxford University Press, pp. 154-183.

https://doi.org/10.1093/acprof:oso/9780199793358.003.0008

Statistics Norway (2018). Undersøkingssaker starta I løpet av året og avslutta av barnevernet, etter alder og kjønn. Fylke 1993-2017.

https://www.ssb.no/a/barnogunge/2018/tabeller/barnevern//barnev0600.html [Accessed 20.1.2019].

Statistical Yearbook (2017). Vilnius. https://osp.stat.gov.It/services-portlet/pubedition-file?id=28260 [Accessed 15.04.2019].

Studsrød, I., Ellingsen, I. T., Guzmán, C. M., \& Espinoza, S. E. M. (2018).

Conceptualizations of family and social work family practice in Chile, Mexico and Norway. Social Policy and Society.17(4), 637 - 649.

https://doi.org/10.1017/S1474746418000234

Taumutiene, I. (2018). Alcohol-related child maltreatment: Reports to the Child Right Protection in Kaunas Municipality. Nordic Studies on Alchohol and Drugs 35(1), 9-23. https://doi.org/10.1177/1455072517749132

Thévenon, O. (2011). Family policies in OECD countries: A comparative analysis. Population and Development Review, 37(1), 57-87. https://doi.org/10.1111/j.1728-4457.2011.00390.x

Walsh, J., White, S., Morris, K., \& Doherty, P. (2018). How do you solve a problem like Maria? Family complexity and institutional complications in UK social work. European Journal of Social Work 22(6), 1050-1061 https://doi.org/10.1080/13691457.2018.1461068 